\title{
KELEMAHAN NORMATIF PENGATURAN TINDAK PIDANA \\ DALAM PASAL 2 DAN PASAL 3 UNDANG-UNDANG NOMOR 31 \\ TAHUN 1999 TENTANG PEMBERANTASAN TINDAK PIDANA KORUPSI DAN PERUBAHANNYA SERTA UPAYA PENYEMPURNAANNYA DALAM RANGKA PEMENUHAN KEWENANGAN DIREKSI BUMD YANG BERBENTUK PERSERO
}

\author{
-Billy Pahlevy Islamy-
}

\begin{abstract}
ABSTRAK
Dalam penelitian ini menghasilkan: Pertama, Pasal 2 dan Pasal 3 UU Tipikor tidak memenuhi asas dalam perumusan tindak pidana yaitu lex certa (harus jelas dan tidak multitafsir) dan lex stricta artinya rumusan tindak pidana itu harus dimaknai tegas dan ketat dan dilarang untuk menganalogikan sehingga tidak mencerminkan kepastian hukum dan bertentangan dengan Pasal 28 D ayat (1) UUD NRI Tahun 1945. Batasan bagi Direksi demi mencapai kepastian hukum dan keadilan adalah dengan penerapan prinsip Business Judgement Rule sebagaimana diatur dalam UU Perseroan Terbatas. Para penegak hukum harus selalu memperhatikan dan menjunjung tinggi asas legalitas dalam penegakan hukum, yang mencerminkan kepastian hukum.
\end{abstract}

Kata Kunci: Tindak Pidana Korupsi, Kewenangan Direksi, BUMD Persero

\begin{abstract}
The results of this research are as follows: First, Article 2 and Article 3 of the Anti-Corruption Act does not meet the principles in the formulation of a crime namely lex certa (must be clear and not multiple interpretations) and lex stricta means the formulation of the criminal act must be interpreted firmly and strictly and is prohibited from analogizing so it is not prohibited from analogizing. reflecting legal certainty and contradicting Article 28 D paragraph (1) of the 1945 Constitution of the Republic of Indonesia. The limitation for the Board of Directors to achieve legal certainty and justice is the application of the Business Judgment Rule principle as regulated in the Limited Liability Company Law. Law enforcers must always pay attention and uphold the principle of legality in law enforcement, which reflects legal certainty.
\end{abstract}

Key words: Corruption Crime, Board of Directors Authority, Regional Owned Enterprises (BUMD) Persero Company.

\section{PENDAHULUAN}

Badan Usaha Milik Daerah (BUMD) adalah badan usaha yang seluruh atau sebagian besar modalnya dimiliki oleh daerah. Suatu daerah dengan otonominya, dalam upaya peningkatan ekonominya dapat membentuk Badan Usaha Milik Daerah (BUMD) sendiri, baik untuk tujuan Public Service, Profit Oriented atau kombinasi keduanya. Dalam bahasa Inggris bentuk usaha atau bentuk hukum perusahaan disebut company atau corporation. ${ }^{1}$ Dalam menjalankan suatu badan usaha, perananan organ dalam perusahaan tersebut sangatlah berpengaruh bagi jalannya perusahaan tersebut, karena hal ini juga terkait dengan keberhasilan BUMD itu sendiri sesuai dengan tujuan pembentukannya. Seperti halnya dalam BUMD yang berbentuk perusahaan perseroan daerah yang memiliki organ kepengurusan yang terdiri dari Rapat Umum Pemegang Saham, Komisaris dan Direksi. Kesemuanya memiliki peran yang penting bagi keberlangsungan BUMD yang berada dalam kepengurusannya. Ketentuan PP Nomor 54 Tahun 2017 telah menetapkan bahwa anggota Direksi wajib dengan itikad baik dan tanggung jawab menjalankan tugas untuk kepentingan dan usaha BUMD, dan setiap anggota Direksi bertanggung

\footnotetext{
${ }^{1}$ Abdulkadir Muhammad, Hukum Perusahaan Indonesia, Bandung, PT. Citra Aditya Bakti, 2010, hlm. 1.
} 
jawab penuh secara pribadi apabila yang bersangkutan bersalah atau lalai menjalankan tugasnya. Sedangkan terkait dengan pengajuan gugatan oleh pemegang saham pada perusahaan perseroan Daerah mengacu pada dengan ketentuan peraturan perundang-undangan yang mengatur mengenai perseroan terbatas. Direksi BUMD seringkali terjerat kasus dugaan melakukan tindak pidana korupsi, direksi BUMD seringkali didakwa dengan ketentuan Pasal 2 dan 3 Undang-Undang Nomor 31 Tahun 1999 Pemberantasan Tindak Pidana Korupsi dan Perubahannya (Lembaran Negara Republik Indonesia Tahun 1999 Nomor 75, Tambahan Lembaran Negara Republik Indonesia Nomor 4150) selanjutnya disingkat sebagai UU Tipikor. Terdapat perbedaan unsur dalam kedua pasal tersebut. Pasal 2 UU Tipikor mempunyai unsur memperkaya diri sendiri, orang lain atau korporasi, yang kedua unsur melawan hukum dan dapat merugikan negara atau perekonomian negara. Sedangkan Pasal 3 UU Tipikor memiliki 3 unsur yakni dengan tujuan menguntungkan diri sendiri, menyalahgunakan kewenangan, kesempatan atau sarana yang ada padanya karena jabatan atau kedudukan, dan unsur yang ketiga adalah dapat merugikan keuangan negara. Dalam hal ini tentu memunculkan berbagai macam pertanyaan-pertanyaan terkait dengan subjek dalam ketentuan Pasal 2 dan Pasal 3 UU Tipikor, karena seperti diketahui bahwa secara historis ketentuan Pasal 2 ayat 1 dan Pasal 3 UU Tipikor berasal dari norma hukum yang terdapat dalam Pasal 1 ayat 1 huruf a dan b UU Nomor 3 Tahun 1971 tentang Pemberantasan Tindak Pidana Korupsi yang lama yang kemudian diadopsi ke dalam UU Tipikor dengan melakukan sedikit perubahan pada beberapa frase.

Dalam ketentuan Pasal 2 dan 3 UU Tipikor tidak tergambar soal unsur mens rea atau niat jahat atau sikap batin pelaku perbuatan pidana dalam unsur melawan hukum, apakah sengaja, apakah lalai, hal ini tidak terlihat dan tidak secara tegas dijelaskan. Sehingga hal ini

${ }^{2}$ Heyder Affan, Dahlan Iskan Dan Tiga Kasus Dugaan Korupsi Yang Menjerat Dirinya, hlm.1, tentu menimbulkan celah-celah hukum yang dapat menetapkan seseorang telah melakukan tindak pidana korupsi, padahal kenyataanya bukan termasuk tindak pidana korupsi. Sehingga prosedur administratif diabaikan atau adanya unsur-unsur lain di luar mens rea atau niat jahat yang dianggap sebagai unsur dalam Pasal 2 dan 3 UU Tipikor tersebut. Hal ini juga terkait dengan penetapan sanksi pidana kepada direksi perusahaan perseroan BUMD dengan adanya dugaan tindak pidana korupsi. Karena seperti diketahui bahwa sesuai dengan asas hukum pidana yakni ultimum remidium yang diartikan bahwa keberadaan sanksi pidana diletakkan atau diposisikan sebagai sanksi terakhir. Artinya dalam suatu Undang-Undang yang pertama kali diatur atau ditetapkan adalah saknsi administratif atau sanksi perdata, sebelum sanksi pidana. Sanksi pidana merupakan obat atau usaha terakhir dari rangkaian tahapan penegakan suatu aturan hukum. Obat terakhir dalam hal ini merupakan senjata pamungkas apabila mekanisme penegakan pada bidang hukum lain tidak bekerja secara efektif. Namun pada kenyataanya saat ini asas ini tidak selalu diterapkan dalam proses penegakan hukum, justru sanksi pidanalah yang menjadi pilihan utama (premimium remidium).

Contoh nyata kasus yang pernah terjadi adalah kasus yang menimpa Dahlan Iskan. Dalam kasus korupsi penjualan Aset milik PT. Pancas Wira Usaha, milik BUMD Jawa Timur. Seluruh aset milik BUMD Jatim yang dijual, selama Dahlan Iskan menjabat sebagai Direksi yaitu tepatnya sebagai direktur utama PT Pancas Wira Usaha pada 2000-2010, dilepas di bawah standar Nilai Jual Obyek Pajak (NJOP). Dahlan Iskan mengakui dirinya menyetujui penjualan aset itu dan menandatangani dokumennya. ${ }^{2}$ Dahlan Iskan dipandang telah menyalahgunakan kekuasaan. Dalam kasus ini Dahlan Iskan divonis 2 Tahun Penjara dan denda 100 juta subsider 2 bulan penjara. Adapun yang menjadi alasan penjualan aset tersebut karena pertama Dahlan Iskan sebagai direksi kesulitan dalam

dalamhttp://www.bbc.com/indonesia/indonesia38851898, diunduh pada 3 Januari 2019. 
pengembangan pengelolaan PT Pancas Wira Usaha Jatim, walaupun saat itu Dahlan Iskan telah merelakan menjaminkan dana pribadi hingga Rp. 40.000.000.000,- (empat puluh miliar) sebagai jaminan di bank, untuk mengembangkan dan memajukan perusaahan milik daerah tersebut. ${ }^{3}$ Pasal 2 ayat (1) dan Pasal 3 Undang-Undang Nomor 31 Tahun 1999 sebagaimana diubah dengan UndangUndang Nomor 20 Tahun 2001 tentang Pemberantasan Tindak Pidana Korupsi (UU Tipikor) tersebut multitafsir sehingga tidak mencerminkan adanya kepastian hukum. Yakni terkait dengan unsur "dapat merugikan keuangan negara" yang tidak mempunyai keseragaman artinya tidak ada sinkronisasi dan harmonisasi antara Undang-Undang (UU) lain yang berlaku. frasa "atau orang lain atau suatu korporasi" dalam Pasal 2 ayat (1) dan Pasal 3 UU Tipikor menimbulkan kerancuan dan menimbulkan ketidakpastian hukum dalam praktik penegakan hukum. Sejak terbitnya UU Tipikor, pejabat atau aparatur administrasi negara, termasuk direksi BUMN atau BUMD cenderung tidak berani mengambil keputusan dalam lingkup administrasi karena ancaman terjerat tindak pidana korupsi. Padahal, mereka melakukannya dalam rangka pelayanan publik dan pemenuhan hak-hak masyarakat. Kepastian hukum merupakan salah satu tujuan diberlakukannya hukum, dalam hal ini ketentuan Pasal 2 dan 3 Undang-Undang Tipikor, memiliki beberapa kelemahan dari segi perumusan unsur Pasalnya, sehingga masih menimbulkan celah hukum dan kesewenang-wenangan dalam menafsirkan ketentuan Pasal tersebut, karena belum terpenuhinya suatu kepastian terkait ketentuan Pasal tersebut, sebagaimana telah dijelaskan diatas. Seperti telah diketahui bersama ketentuan tersebut merupakan delik materiil yang mensyaratkan adanya akibat yang ditimbulkan sehingga dapat diklasifikasikan

\footnotetext{
${ }^{3}$ Dian Kurniawan, Alasan Dahlan Iskan Jual Aset Panca Wira, dalam http://regional.liputan6.com/read/2910595/alasan-dahlaniskan-jual-aset-pancawira, diunduh pada 3 Januari 2019. ${ }^{4}$ Ronny, 1990, Hanitijo Soemitro, Metodologi Penelitian Hukum, Ghalia Indonesia, Jakarta, hlm. 11.
}

memenuhi unsur Pasal tersebut, namun di dalam prakteknya, ketentuan Pasal tersebut sering kali ditafsirkan berbeda-beda, sehingga tidak mencapai suatu kepastian hukum. Secara normatif suatu kepastian hukum adalah ketika suatu peraturan dibuat dan diundangkan secara pasti karena mengatur secara jelas dan logis. Jelas dalam artian tidak menimbulkan keraguraguan dan logis tidak menimbulkan benturan dan kekaburan norma dalam sistem norma satu dengan yang lainnya. Sehingga berdasarkan hal tersebut menarik untuk dikaji terkait kelemahan normatif pengaturan tindak pidana dalam Pasal 2 dan Pasal 3 UndangUndang Nomor 31 Tahun 1999 tentang pemberantasan tindak pidana korupsi dan perubahannya serta upaya penyempurnaannya dalam rangka pemenuhan kewenangan direksi BUMD yang berbentuk Persero.

\section{METODE PENELITIAN}

Jenis penelitian yang digunakan dalam penelitian ini adalah yuridis normatif yang dapat diartikan sebagai penelitian hukum kepustakaan yang dilakukan berdasarkan pada kepustakaan atau data sekunder ${ }^{4}$. Dengan kata lain penelitian ini penelitian kepustakaan (library reseach) artinya penelitian ini dilakukan dengan membaca karya-karya yang terkait dengan persoalan yang akan dikaji kemudian memuat kajian tentang penelitian ${ }^{5}$. Adapun metode pendekatan yang digunakan dalam penelitian hukum ini adalah suatu Pendekatan perundangundangan atau (statue approach), pendekatan konsep (conseptual approach), pendekatan kasus (case approach), pendekatan sejarah ((historical approach). ${ }^{6}$

Sedangkan tekhnik pengumpulan bahan hukum yang digunakan dalam penilitian ini adalah dengan melakukan "library research". Teknik library reseach adalah teknik pengumpulan bahan hukum dengan melakukan

\footnotetext{
${ }^{5}$ Mestika Zed, 2007, Metode Penelitian Kepustakaan, Yayasan Obor Indonesia, Jakarta, hlm. 3.

${ }^{6}$ Johnny Ibrahim, 2007, Teori \& Metodologi Penelitian Hukum Normatif, cet. III, Bayu Media Publishing, Malang, hlm. 321.
} 
studi kepustakaan yang memiliki keterkaitan dengan objek kajian permasalahan yang akan diteliti. Sedangkan tekhnik analisis badan hukum yang digunakan dalam penelitian ini adalah dengan interpretasi gramatikal dan interpretasi teleologis atau sosiologis. ${ }^{7}$

\section{HASIL DAN PEMBAHASAN}

1. Kelemahan Pengaturan Perbuatan Pidana dalam Pasal 2 dan 3 Undang-Undang Nomor 31 Tahun 1999 tentang Pemberantasan Tindak Pidana Korupsi dan Perubahannya kaitannya dengan Pemenuhan Kewenangan Direksi dalam Mengelola Perusahaan BUMD yang Berbentuk Persero.

Unsur-unsur delik dalam Pasal 2 dan 3 Undang-Undang Pemberantasan Tindak Pidana Korupsi tersebut bersifat kumulatif, artinya untuk dapat dijatuhi pidana karena korupsi, maka semua unsur delik harus terpenuhi dan dapat dibuktikan oleh jaksa penuntut umum. Apabila salah satu unsur delik tidak terpenuhi, maka seseorang tidak dapat dikatakan telah melakukan suatu perbuatan pidana. Sudarto mengatakan bahwa dipidananya seseorang tidaklah cukup apabila orang itu telah melakukan perbuatan yang bertentangan dengan hukum atau bersifat melawan hukum. Untuk dapat dilaksanakan sebuah pemidanaan masih perlu adanya syarat, bahwa orang yang melakukan perbuatan itu mempunyai kesalahan atau bersalah (subjective guilt). Dengan kata lain, orang tersebut harus dapat dipertanggungjawabkan atas perbuatannya atau jika dilihat dari sudut perbuatannya baru dapat dipertanggungjawabkan kepada orang tersebut. Di sini berlaku apa yang disebut asas "tiada pidana tanpa kesalahan" (geen straf zonder schuld). ${ }^{8}$ Pasal 2 dan Pasal 3 Undang-Undang Tindak Pidana Korupsi sangat memungkinkan Direksi dikenai tindak pidana korupsi dengan adanya tindakan mengeluarkan keputusan dalam

\footnotetext{
${ }^{7}$ Sudarsono, 2007, Pengantar Ilmu Hukum, Rineka Cipta, Jakarta, hlm. 123.

${ }^{8}$ Muladi \& Dwidja Priyanto, 2012, Pertanggungjawaban Pidana Korporasi, Edisi Revisi,
}

hal pelaksanaan kebijakan dalam suatu korporasi, memungkinan merugikan Negara.

\section{a. Kelemahan Pengaturan Perbuatan Pidana} dalam Pasal 2 dan 3 Undang-Undang Nomor 31 Tahun 1999 tentang Pemberantasan Tindak Pidana Korupsi dikaitkan dengan Asas Lex Certa, Lex Scripta dan Lex Stricta.

Asas legalitas sering digambarkan dalam adagium "dikatakan tidak ada perbuatan, yang dapat dihukum tanpa peraturan yang mendahuluinya". Asas Legalitas secara umum memberikan batasan terhadap kekuasaan negara, sehingga negara tidak secara sewenang- wenang dapat menentukan suatu perbuatan warga Negara adalah perbuatan pidana sehingga dapat dihukum. Dalam perkembangannya asas legalitas diartikan dalam empat prinsip dasar yaitu lex scripta, lex certa, lex stricta dan lex praevia. Lex scripta artinya hukum pidana tersebut harus tertulis. Lex certa artinya rumusan delik pidana itu harus jelas. Lex stricta artinya rumusan pidana itu harus dimaknai tegas tanpa ada analogi. dan lex praevia yang aritnya hukum pidana tidak dapat diberlakukan surut. Pasal 2 ayat (1) dan Pasal 3 Undang-Undang Nomor 31 Tahun 1999 sebagaimana diubah dengan Undang-Undang Nomor 20 Tahun 2001 tentang Pemberantasan Tindak Pidana Korupsi (UU Tipikor) tidak memenuhi asas lex certa (harus dirumuskan secara jelas dan tidak multitafsir). Pasal tersebut multitafsir sehingga tidak mencerminkan adanya kepastian hukum. Yakni terkait dengan unsur "dapat merugikan keuangan negara" yang tidak mempunyai keseragaman artinya tidak ada sinkronisasi dan harmonisasi antara Undang-Undang (UU) lain yang berlaku. Misalnya, Undang-Undang Perseroan Terbatas (UU PT) dan UndangUndang tentang Badan Usaha Milik Negara (UU BUMN) menyebut sumber keuangan yang berasal dari negara ketika ditempatkan dalam perseroan terbatas atau BUMN merupakan kekayaan terpisah dan tidak termasuk kategori

Cetakan Ketiga, Sekolah Tinggi Hukum Bandung, Jakarta, hlm 71 . 
keuangan negara, hal ini tentu berlaku pula pada BUMD. Pasal 2 ayat (1) dan Pasal 3 UndangUndang Tipikor menimbulkan kerancuan dan menimbulkan ketidakpastian hukum dalam praktik penegakan hukum sehingga tidak memenuhi asas dalam perumusan tindak pidana, terutama asas lex certa (secara jelas) dan lex stricta (secara ketat). Sejak terbitnya UU Tipikor, pejabat atau aparatur administrasi negara termasuk direksi perusahaan BUMN maupun BUMD cenderung tidak berani mengambil keputusan dalam lingkup administrasi karena takut terjerat tindak pidana korupsi. Padahal hal tersebut dilakukan dalam rangka pelayanan publik dan pemenuhan hakhak masyarakat. Seharusnya apabila ada kesalahan administrasi dari kebijakan yang diambil cukup dilakukan penyempurnaan prosedur administrasi atau tindakan sanksi administratif, bukan dipidanakan. Apabila dalam pemeriksaan itu diduga ada unsur tindak pidana (delik korupsi), atas permintaan penyidik dapat dilakukan pemeriksaan untuk tujuan tertentu yang disebut investigation audit. Intinya kesalahan administrasi tidak serta merta mengandung unsur perbuatan melawan hukum (tipikor) dan perbuatan melawan hukum itu dapat dilakukan tanpa adanya kesalahan administrasi. Unsur Pasal 2 dan Pasal 3 khususnya frasa "merugikan keuangan negara" dan "atau orang lain atau korporasi" tersebut jelas bertentangan dengan prinsip perumusan tindak pidana yang harus memenuhi prinsip ketentuan hukum yang harus ditafsirkan seperti yang dibaca(lex stricta), dan tidak multitafsir (lex certa), karena dalam hal ini unsur Pasal tersebut tidak memenuhi asas lex stricta dan lex certa. Maksud dari kepastian hukum adalah bahwa hukum yang dibuat harus memenuhi asas lex scripta (harus tertulis), lex certa (tidak multitafsir) dan harus ditafsirkan lex stricta (secara ketat). Kata lain, secara formil sebuah ketentuan perundang-undangan haruslah dituangkan dalam bentuk tertulis secara

${ }^{9}$ H. Abdul Latif, 2014, Hukum Administrasi Dalam Praktik Tindak Pidana Korupsi, Prenada Media Group, Jakarta, hlm. 295 sistematis yang dapat ditafsirkan secara ketat dan tidak multitafsir. Sedangkan unsur "merugikan keuangan negara" dan "atau orang lain atau korporasi" tidak memenuhi asas lex certa yakni perumusan tindak pidana harus jelas dan tidak multitafsir dan asas lex stricta yang berarti rumusan tindak pidana itu harus dimaknai tegas artinya ketentuan itu harus ditafsirkan secara sempit, tidak boleh dilakukan analogi. Sehingga ketentuan tersebut bertentangan dengan ketidakpastian hukum (rechtsonzekerheid) yang dijamin konstitusi, dalam pasal 28D ayat (1) UUD 1945. Akibatnya penegak hukum berpotensi melakukan tindakan penyalahgunaan wewenang atau tindakan sewenang-wenang dalam melakukan proses hukum yang bertentangan dengan proses hukum yang adil (due proces of law) yang dijamin oleh konstitusi dalam UUD 1945. ${ }^{9}$

\section{b. Kelemahan Unsur Pasal 2 dan Pasal 3 UU Tipikor dikaitkan dengan Asas Kepastian Hukum.}

Rumusan Pasal 2 dan Pasal 3 UU Tipikor memiliki persamaan dalam tujuan yaitu pengembalian kerugian keuangan negara dan memberikan efek jera, selain itu unsur memperkaya dalam Pasal 2 dan unsur menguntungkan dalam Pasal 3 UU Tipikor mempunyai pengertian yang sama (identik) ${ }^{10}$ yaitu tujuan penambahan kekayaan diri sendiri, orang lain atau suatu korporasi. Perbedaanya terdapat pada subjek hukum dan unsur perbuatan secara melawan hukum dalam Pasal 2 dan menyalahgunakan wewenang dalam Pasal 3 UU Tipikor. Namun dalam praktiknya seringkali tertukar, di mana hakim membenarkan tuntutan Jaksa Penuntut Umum terhadap orang yang bukan penyelenggara negara dituntut melanggar Pasal 3, dan sebaliknya seorang penyelenggara dituntut melanggar Pasal 2, seperti halnya dalam kasus korupsi Andi Malaranggeng yang merupakan penyelenggara negara didakwa dengan Pasal 2 (Primair) dan Pasal 3 (Subsidair), yang seharusnya Pasal 3 sebagai dakwaan

\footnotetext{
${ }^{10}$ Nur Basuki Minarno, 2009, Penyalahgunaan Wewenang dan Tindak Pidana Korupsi dalam Pengelolaan Keuangan Daerah, Cetakan Kedua, Yogyakarta, hlm. 32
} 
primairnya. Perbedaan subjek hukum dan tujuan kedua pasal tersebut tidak diperhatikan atau dipertimbangkan oleh majelis hakim. ${ }^{11}$ Dengan demikian Pasal 2 dan Pasal 3 UU Tipikor akan lebih efisien jika dirumuskan dalam satu pasal saja, selain itu dapat menghindarkan penegak hukum dari kesalahan memahami esensi kedua pasal tersebut. Kelemahan dalam ketentuan Pasal 2 dan Pasal 3 UU Tipikor terbukti dengan para penegak hukum, termasuk Mahkamah Agung (MA) masih keliru memahami Pasal 2 dan Pasal 3 Undang-Undang Nomor 31 Tahun 1999 tentang Pemberantasan Tindak Pidana Korupsi (UU Tipikor). Dalam hal ini karena majelis hakim lebih menekankan pada unsur kerugian Negara daripada unsur memperkaya diri sendiri. Seharusnya, cara pembuktiannya terbalik, yakni membuktikan unsur perbuatan memperkaya diri sendiri terlebih dahulu, baru membuktikan unsur kerugian Negara. Kesalahpahaman tersebut tentu berakibat menimbulkan ketidakpastian hukum. Kepastian hukum merupakan salah satu tujuan diberlakukannya hukum, dalam hal ini ketentuan Pasal 2 dan 3 Undang-Undang Tipikor, memiliki beberapa kelemahan dari segi perumusan unsur Pasalnya, sehingga masih menimbulkan celah hukum dan kesewenang-wenangan dalam menafsirkan ketentuan Pasal tersebut, karena belum terpenuhinya suatu kepastian terkait ketentuan Pasal tersebut, sebagaimana telah dijelaskan diatas. Seperti telah diketahui bersama ketentuan tersebut merupakan delik materiil yang mensyaratkan adanya akibat yang ditimbulkan sehingga dapat diklasifikasikan memenuhi unsur Pasal tersebut, namun di dalam prakteknya, ketentuan Pasal tersebut sering kali ditafsirkan berbeda-beda, sehingga tidak mencapai suatu kepastian hukum. Secara normatif suatu kepastian hukum adalah ketika suatu peraturan dibuat dan diundangkan secara pasti karena mengatur secara jelas dan logis. Jelas dalam artian tidak menimbulkan keraguraguan dan logis tidak menimbulkan

11 Romli Atmasasmita \& Kodrat Wibowo, 2016, Analisis Ekonomi Mikro tentang Hukum Pidana Indonesia, Cetakan kesatu, Prenadamedia Group, Jakarta, hlm 207. benturan dan kekaburan norma dalam sistem norma satu dengan yang lainnya. Kekaburan norma yang ditimbulkan dari ketidakpastian aturan hukum, dapat terjadi multi tafsir terhadap sesuatu dalam suatu aturan. Kepastian hukum merupakan kesesuaian yang bersifat normatif baik ketentuan maupun keputusan hakim. Kepastian hukum merujuk pada pelaksana tata kehidupan yang dalam pelaksanaannya jelas, teratur, konsisten, dan konsekuen serta tidak dapat dipengaruhi oleh keadaan-keadaan yang sifatnya subjektif dalam kehidupan masyarakat.

\section{c. Kelemahan Ketentuan Pasal 2 dan 3 UU Tipikor dalam Perumusan Unsur Pasal dan Penerapannya dikaitkan dengan Asas Pembentukan Peraturan Perundang- Undangan.}

Kelemahan ketentuan Pasal 2 dan 3 UU Tipikor terdapat dalam perumusan unsur dan penerapannya, yakni sebagai berikut:

1. Penerapan Subjek Tindak Pidana

Terkait dengan penerapan Pasal 2 ayat (1) Undang-Undang Nomor 3 Tahun 1999, tersebut terjadi kerancuan karena seharusnya pasal tersebut tidak dapat diterapkan kepada pihak non pegawai negeri atau kepada pihak swasta., termasuk direksi BUMD dan BUMN ${ }^{12}$ Akan tetapi dalam praktiknya sebaliknya bahkan perkembangannya pasal ini pun diterapkan untuk menjerat korporasi yang melakukan tindak pidana korupsi. Penerapan tersebut tidak bisa lepas dari pengertian pegawai negeri dalam Undang-Undang No. 31 Tahun 1999 sendiri. Terjadi perluasan makna pegawai negeri dalam Pasal 1 angka 2 Undang-Undang Nomor 31 Tahun 1999 yang meliputi orang yang menerima gaji atau upah dari korporasi lain yang mempergunakan modal atau fasilitas dari negara atau masyarakat. Dalam praktiknya, Pasal 2 ayat (1) UU Tipikor diterapkan kepada subjek tindak pidana korupsi dari pihak non pegawai negeri atau pihak

12 Darwan Prinst, 2002, Pemberantasan Tindak Pidana Korupsi, PT Citra Aditya Bakti, Bandung, hlm. 29. 
swasta, sedangkan Pasal 3 Undang-Undang Nomor 31 Tahun 1999 diterapkan kepada subjek tindak pidana korupsi dari pihak pegawai negeri atau pejabat umum.

2. Penerapan Unsur Melawan Hukum Perlu ditegaskan bahwa kualifikasi perbuatan melawan hukum dalam hukum pidana berbeda dengan kualifikasi dengan perbuatan melawan hukum perdata maupun dalam hukum administrasi negara. Dalam praktiknya hakim kerap kali mencampuradukkan antara perbuatan melawan hukum dalam hukum pidana dengan hukum perdata maupun administrasi negara. Permasalahan terkait dengan penerapan unsur melawan hukum pada Pasal 2 ayat (1) Undang-Undang Nomor 31 Tahun 1999 terletak pada permasalahan apakah perbuatan melawan hukum yang dilakukan oleh pelaku dapat dikualifikasikan sebagai unsur melawan hukum dalam pengertian hukum pidana. Pengertian melawan hukum "wederrechtelijk" dalam hukum pidana sering dicampuradukan dengan pengertian pengertian melawan hukum "onrechmatigedaad" dalam hukum perdata. Akibatnya perbuatan dipandang tercela dalam masyarakat yang seharusnya masih dalam area hukum perdata kemudian dikualifikasikan sebagai melawan hukum dalam hukum pidana.

3. Penerapan Unsur Memperkaya Diri Sendiri atau Orang Lain atau Badan. Dalam hal ini tidak satupun ditemukan adanya kesamaan rumusan tentang pengertian "memperkaya" maupun "menguntungkan" baik dalam pengaturan undang-undang maupun menurut pendapat para ahli di dalam menentukan suatu jumlah nilai tertentu, atau kriteria/ukuran seseorang atau korporasi dapat dikatakan sebagai suatu hal memperkaya atau menguntungkan, kecuali hanya menyatakan adanya pertambahan harta bagi pelaku/orang lain/suatu korporasi. Apalagi bila mencermati redaksi pasal-pasal seperti unsur "memperkaya" dan atau unsur "menguntungkan" di dalam undangundang dimaksud, yang belum diatur secara jelas tentang kriteria atau definisi atau pengertiannya, sehingga dapat berdampak multitafsir.

4. Penerapan Unsur Merugikan Keuangan Negara atau Perekonomian Negara.

Dalam UU Tipikor (Pasal 2 dan Pasal 3 UU Tipikor) telah mengatur mengenai unsur "kerugian keuangan negara" sebagai salah satu rumusan delik korupsi, namun regulasi ini tidak menyebutkan secara jelas dan tegas mengenai siapa instansi atau pihak mana yang berwenang dalam menentukan penghitungan kerugian negara. Kondisi ini pada praktiknya menyebabkan multitafsir dan persoalan mengenai siapa yang berwenang dalam penghitungan dan penentuan kerugian keuangan negara perlu dibuat kesepahaman antara lembaga penegak hukum dan lembaga audit negara (BPKP dan BPK) dalam kaitannya mengatasi hambatan-hambatan yang muncul dalam pelaksaanaan penanganan perkara korupsi khususnya yang berkaitan dengan penerapan unsur kerugian keuangan Negara, selain itu, BPK dan BPKP harus menjadi lembaga yang menentukan langkah penindakan dalam hal jika terjadi kerugian dalam BUMD, apakah hanya sebatas diperlukan tindakan administratif (administrative measure) ataukan akan diteruskan ke penyidik. Penyidik dan penuntut tidak memiliki wewenang lebih jauh memasuki wilayah keuangan negara yang secara administratif merupakan wilayah pengawasan BPK dan BPKP.

d. Penerapan Pasal 2 dan Pasal 3 UU Tipikor dikaitkan dengan Kewenangan Direksi dalam 
Pengurusan Perseroan Terbatas (BUMD Persero).

Kewenangan direksi untuk mewakili Perseroan bersifat tidak terbatas dan tidak bersyarat, kecuali ditentukan lain dalam UUPT, anggaran dasar atau keputusan Rapat Umum Pemegang Saham ("RUPS"). Kewenangan yang dimiliki oleh Direksi dalam menjalankan tugasnya dalam suatu perusahaan, dalam hal ini BUMD, mempunyai risiko yang sangat tinggi, terutama terkait dengan keputusannya yang dapat merugikan Perseroan. Namun dalam hal ini bila diteliti terkit dengan unsur-unsur Pasal UU Tipikor, dari segi subjek hukum, tidak secara tegas disebutkan bahwa Direksi BUMD merupakan subjek hukum yang dimaksud Pasal 2 maupun Pasal 3 UU Tipikor. Selain itu dalam hal ini harus terpenuhi pula unsur merugikan keuangan negara, namun seperti diketahui bahwa keuangan BUMN/BUMD yang berbentuk PT bukanlah keuangan negara, melainkan keuangan PT sebagai badan hukum. Terdapat perbedaan konsep keuangan negara dengan keuangan BUMN/BUMD yang dikelola dalam bentuk Perseroan Terbatas. Keuangan BUMN/BUMD apabila telah dikelola oleh sebuah PT sebagai badan hukum, maka keuangannya merupakan keuangan Perseroan Terbatas tersebut. Ketentuan mengenai Pasal 2 dan Pasal 3 yang merupakan delik materiil, dalam penerapannya aparat penegak hukum seharusnya tidak dengan mudahnya menetapkan seseorang sebagai tersangka korupsi sebelum ada bukti kerugian keuangan negara yang berunsur pidana (korupsi). Sebab, tak jarang praktiknya ketika BPK belum merekomendaskan audit investigasi kerugian negara, penyidik sudah menetapkan seseorang sebagai tersangka. Dalam hal ini pengaturan ketentuan Pasal 2 dan 3 UU Tipikor kedepan harus memiliki unsur yang jelas, salah satunya terkait subjek hukum yang dapat dijerat dengan Pasal tersebut, sehingga terjadi keseragaman dan konsistensi dalam penerapan Pasal tersebut, sehingga tidak terjadi lagi multitafsir, yang menyebabkan tercorengnya nilai keadilan dan kepastian hukum. Mengingat tujuan dari berlakunya norma hukum yaitu menjamin kepastian hukum dalam hubungan-hubungan yang ada dalam masyarakat, sehingga tidak terjadi lagi kesewenang-wenangan tindakan dari aparat penegak hukum akibat ketidakjelasan norma hukum itu sendiri.

\section{Batasan Pengaturan Perbuatan} Pidana dalam Pasal 2 dan 3 UndangUndang Nomor 31 Tahun 1999 tentang Pemberantasan Tindak Pidana Korupsi dan Perubahannya Agar Tidak Menjadi Penghambat Pemenuhan Kewenangan Direksi dalam Mengelola Perusahaan BUMD Persero.

Direksi BUMD merupakan bagian dari organ BUMD yang tunduk kepada domain hukum privat. Sehingga, apabila kerugian BUMD yang dikaitkan dengan kerugian Negara, maka membuat Direksi tidak leluasa membuat keputusan bisnis, hal ini telah menjadi suatu hal membahayakan bagi tugas seorang Direksi BUMD dan ketakutan setiap hendak mengambil keputusan bisnis karena khawatir akan diduga melakukan tindak pidana korupsi apabila di kemudian hari keputusannya dinilai menyebabkan kerugian negara. Hal ini berakibat pada pengambilan keputusan yang lebih lama. Sedangkan dalam dunia usaha Direksi diminta membuat business judgment (keputusan bisnis yang cepat).

a. Pengecualian Pertanggungjawaban Direksi BUMD dikaitkan dengan Asas Business Jugement Rule.

Perseroan Terbatas dalam kegiatannya dijalankan oleh organ yang disebut Direksi, dikatakan Direksi sebab organ perusahaan ini didalamnya terdiri dari satu atau lebih 
Direktur. ${ }^{13}$ Business judgment rule merupakan salah satu doktrin yang ada dalam hukum perusahaan yang memberikan perlindungan terhadap direksi perusahan untuk tidak bertanggungjawab atas kerugian yang timbul dari suatu konsekuensi apabila tindakan direksi didasarkan pada itikad baik dan sifat hati-hati. Business judgment rule sebenarnya mengenai pembagian tanggung jawab di antara perseroan dan organ yang mengurusnya, terutama direksi, dan pemegang saham manakala terjadi kerugian yang menimpa perseroan yang diakibatkan oleh kesalahan manusia. Black's Law Dictionary mendefinisikan business judgment rule sebagai suatu tindakan dalam membuat suatu keputusan bisnis tidak melibatkan kepentingan diri sendiri, kejujuran dan mempertimbangkan yang terbaik bagi perusahaan (the presumption that in makin business decision not involving direct self interest or self dealing, corporate directors act in the honest belief that their actions are in the corporation best interest ). Business judgment rule ini merupakan doktrin yang mengajarkan bahwa keputusan direksi mengenai aktivitas perseroan tidak dapat langsung dipersalahkan oleh siapa pun meski keputusan tersebut merugikan perseroan. Doktrin business judgement rule adalah suatu sumber hukum yang mengatur pemberian kekebalan atau perlindungan bagi direksi perseroan dari setiap tanggung jawab yang lahir sebagai akibat dari transaksi atau kegiatan yang dilakukan direksi sesuai dengan batas kewenangan dan kekuasaan yang diberikan. Hal itu dengan pertimbangan aksi korporasi dilakukan dengan memperhatikan standar kehati-hatian dan iktikad baik. Pasal 92 dan Pasal 97 Undang-Undang Nomor 40 Tahun 2007 tentang Perseroan Terbatas mengatur bahwa direksi tidak dapat dimintakan tanggungjawabnya hanya karena alasan salah dalam memutuskan (mere error of judgement) atau hanya karena alasan kerugian perseroan. Sehingga, jika ada kesalahan dalam perbuatan

13 Tuti Rastuti, 2015, Seluk Beluk Perusahaan \& Hukum Perusahaan, Rafika Aditama Bandung, hlm. 167

${ }^{14} \mathrm{https}: / /$ mediaindonesia.com/read/detail/189924business-judgment-rule-versus-tindak-pidana-korupsi, diakses pada 1 April 2019. administrasi maka tidak terdapat sanksi pidana. Dugaan perbuatan melawan hukum tersebut bukanlah dapat digolongkan sebagai perbuatan atau tindak pidana, terlebih korupsi, karena terlebih dahulu harus menundukkan diri ke dalam ketentuan yang lebih khusus, yaitu Undang-Undang Perseroan Terbatas. Prinsip 'iktikad baik' yang dinyatakan dalam Pasal 97 ayat (2) UU Perseroan Terbatas mengandung jiwa dan spirit dari doktrin business judgement rule. Yang mana direksi tidak dapat dipersalahkan atas keputusannya sepanjang keputusan itu tidak mengandung unsur kepentingan pribadi, diputuskan berdasarkan informasi yang mereka percaya, oleh keadaan yang tepat dan secara rasional, serta merupakan keputusan yang terbaik untuk perusahaan. ${ }^{14}$ Batasan yang harus dipahami terkait dengan kewenangan direksi dalam pelaksanan kewenangannya dalam mengurus suatu BUMD Persero adalah dengan pelaksanaaan doktrin business judgment rule. Namun kendala yang terjadi saat ini adalah adanya beberapa ketidakpastian, terutama dikarenakan banyaknya pendapat yang berbeda dalam menafsirkan Undang-Undang yang terkait. Salah satu lapangan hukum publik yang menjadi sasaran pemberantasan tindak pidana korupsi adalah BUMN dan BUMD. Para penegak hukum seringkali tidak memahami konsep badan hukum, juga tidak mengerti dan mengabaikan kensekuensi yuridis penyertaan modal oleh Negara dalam bentuk kekayaan Negara yang dipisahkan dan BUMN. Akibatnya setiap kali BUMN maupun BUMD mengalami kerugian, maka organ perseroan, khususnya direksi akan dianggap telah memenuhi Pasal 2 ayat 1 Undang-Undang tentang Pemberantasan Tindak Pidana Korupsi. ${ }^{15}$ Seperti diketahui bahwa dalam menjalankan roda perusahaan, direksi melaksanakan aksi korporasi yang berpotensi memicu kerugian yang disebut sebagai risiko bisnis. Namun, dalam perjalannya

${ }^{15}$ Erman Rajagukguk, 2006, Tetes Pemikiran 1971 2006, Lembaga Studi Hukum dan Ekonomi, Depok, Universitas Indonesia, hlm. 211 
risiko bisnis tersebut berpotensi menimbulkan kerugian BUMD dan diidentikkan sebagai kerugian negara. Hal ini tentu menimbulkan kekhawatiran direksi karena dapat ditarik ke ranah tindak pidana korupsi. Namun, hal tersebut seharusnya dapat ditelaah kembali, sebagaimana yang telah diuraikan diatas, bahwa BUMD Persero adalah bentuk badan usaha yang sama seperti perseroan terbatas yang artinya juga tunduk dengan Undang-Undang Nomor 40 Tahun 2007 tentang Perseroan Terbatas. Jika cara kerja direksi BUMD ditelaah dengan pemikiran berdasarkan Undang-Undang Nomor 40 Tahun 2007 tentang Perseroan Terbatas maka Undang-Undang mengharuskan para direksinya bertindak atau menjalankan tugas dan wewenangnya sebagaimana yang ditentukan oleh Undang-Undang dan Anggaran Dasar. Pelaksanaan tugas dan wewenangnya ini haruslah tetap memenuhi ketentuan fiduciary duty, statutory good faith sebagaimana yang telah diadopsi Indonesia terhadap prinsipprinsip corporate law tersebut. Dengan adanya konsistensi dari direksi untuk melaksanakan fiduciary duty dan statutory good faith, maka secara legal direksi dapat menerapkan prinsip business judgement rule sebagai alasan pemaaf apabila dikemudian hari ada hal yang harus dipertanggungjawabkan oleh direksi. Seharusnya tanggung jawab direksi dalam pengelolaan BUMD didasarkan pada ketentuan Pasal 97 ayat (3) dan (4 UU PT), serta Pasal 1365 KUHPerdata. Pasal 97 ayat (3) UU PT menyatakan bahwa"Setiap anggota direksi bertanggung jawab secara penuh secara pribadi atas kerugian perseroan apabila yang bersangkutan bersalah atau lalai menjalankan tugas dalam mengurus perseroan". Dengan demikian, tanggung jawab direksi dalam pengelolaan BUMD condong kepada pertanggungjawaban perdata karena dalam hal ini termasuk bagian dari hukum privat dan bukan ranah hukum publik. Direksi bisa dituntut ke ranah pidana apabila direksi tersebut melakukan perbuatan penipuan ( $\mathrm{fraud}$ ) atau penggelapan.

Salah satu asas yang menjadi prinsip dasar atau petunjuk sekaligus batasan bagi penegakan hukum yang memberikan ketegasan kepastian hukum dan keadilan yang terdapat dalam Undang-Undang Perseroan Terbatas yaitu asas atau prinsip Business Judgement Rule. Apabila direksi pada saat mengambil keputusan, telah melakukannya dengan pertimbangan yang matang, penuh tanggung jawab, maka mengingat suasana bisnis yang penuh ketidakpastian, seandainya ternyata keputusan tersebut salah, seharusnya direksi tidak dituntut secara pribadi, karena perseroan juga harus ikut menanggung kerugian tersebut, ini adalah konsep dasar business judgment rule. Business judgement rule sebenarnya mengenai pembagian tanggung jawab di antara perseroan dan organ yang mengurusnya, terutama direksi, dan pemegang saham manakala terjadi kerugian yang menimpa perseroan yang disebabkan oleh human error.

\section{b. Pembatasan Kewenangan Direksi dalam Pengurusan BUMD dikaitkan dengan Teori Kewenangan.}

Batasan yang harus diberikan dan diperjelas terkait dengan kewenangan Direksi agar tidak mudah disangkakan dengan UU Tipikor, selain dengan pemberlakuan dan pengefektifan ketentuan business judgment rules yang terdapat dalam UUPT adalah mengenai unsur kerugian negara yang menjadi begitu sentral atau utama dalam penanganan kasus korupsi, dibanding unsur memperkaya diri sendiri/orang lain. Padahal Indonesia merupakan salah satu negara yang meratifikasi United Nations Convention Against Corruption (UNCAC) dengan diundangkannya UU Nomor 7 Tahun 2006 tentang Pengesahan United Nations Convention Against Corruption, 2003 (Konvensi Perserikatan Bangsa-Bangsa Anti Korupsi, 2003) sehingga seharusnya jenis tindak pidana korupsi yang diatur dalam UU Pemberantasan Tindak Pidana Korupsi mengacu pada konvensi tersebut. Kepastian hukum dan keadilan setiap warga negara mutlak diperlukan terutama bagi Direksi yang menjalankan kewenangannya dengan itikad baik demi kepentigan BUMD. Permasalahan terkait ketidakjelasan suatu permasalahan masuk dalam wilayah hukum perdata atau hukum pidana. Semua kondisi tersebut menyebabkan Undang- 
Undang Tindak Pidana Korupsi yang baru mendesak dibentuk karena Undang-Undang Pemberantasan Tindak Pidana Korupsi yang saat ini berlaku sudah tidak sesuai dengan perkembangan zaman. UU Tipikor perlu segera dilakukan revisi. Menurut Soekanto ${ }^{16}$ masalah pokok penegakan hukum sebenarnya terletak pada faktor-faktor yang mempengaruhinya, yaitu:

1. Faktor hukumnya sendiri (undang-undang).

2. Faktor penegak hukum, yakni pihak-pihak yang membentuk maupun menerapkan hukum.

3. Faktor sarana atau fasilitas yang mendukung penegakan hukum.

4. Faktor masyarakat, yakni lingkungan dimana hukum tersebut berlaku atau diterapkan.

5. Faktor kebudayaan, yakni sebagai hasil karya, cipta dan rasa yang didasarkan pada karsa manusia di dalam pergaulan hidup.

Pemahaman keuangan negara dalam BUMN atau BUMD sering diidentikkan dengan aset pemerintah sehingga seluruh piutang maupun hutang BUMN/BUMD adalah piutang maupun hutang dari pemerintah, padahal pemahaman yang benar adalah kekayaan yang yang dipisahkan oleh pemerintah pada BUMN/BUMD adalah bagian dari kekayaan negara atau daerah. Kekayaan negara tersebut adalah sebesar "modal yang disetor" atau "perubahan" nya Undang-Undang No. 1 Tahun 2004 tentang Perbendaharaan Negara menyebutkan: "Piutang Negara/Daerah adalah jumlah yang wajib dibayar kepada Pemerintah Pusat/Daerah dan/atau hak Pemerintah Pusat/Daerah yang dapat dinilai dengan uang sebagai akibat perjanjian atau akibat lainnya berdasarkan peraturan perundang-undangan yang berlaku atau akibat lainnya yang sah".

Piutang BUMN dan BUMD tidak termasuk piutang Negara, karena hasil perolehannya tidak dibayar dan disetor kepada Pemerintah, dan penerimaan tersebut bukan merupakan penerimaan yang dilaporkan pada ABPN atau
APBD. Konsekuensinya, jika perseroan tersebut mengalami kerugian maka tidaklah dapat dikatakan "telah terjadi kerugian atas keuangan negara" dan secara logika juga tidak mungkin dapat dilakukan pemisahan penggunaan harta perseroan yang berasal dari pemegang saham tertentu. Dengan demikian jika suatu BUMN/BUMD (Persero) mengalami kerugian yang diakibatkan oleh Pengurus BUMN/BUMD tersebut dalam menjalankan tugasnya maka tidak ada dampak kerugian keuangan negara dalam hal keuangan negara sebagai tindak pindana korupsi sebagaimana diatur dalam Undang-Undang Pemberantasan Tindak Pidana Korupsi. Tetapi hal tersebut menurut Erman Radjaguguk bisa terjadi jika seseorang dengan sengaja menggelapkan surat berharga (saham) dengan jalan menjual saham tersebut secara melawan hukum yang disimpannya karena jabatannya atau membiarkan saham tersebut diambil atau digelapkan oleh orang lain atau membantu dalam melakukan perbuatan tersebut sebagaimana diatur dalam Pasal 8 UU Tindak Pidana Korupsi. Pembatasan ini tentu harus dipahami oleh para penegak hukum, agar tidak keliri dalam menerapkan hukum.

Sedangkan kewenangan direksi adalah sebagai berikut:

1. Salah satu organ Persoran yang memiliki kewenangan penuh atas pengurusan dan halhal terkait kepentingan Perseroan sesuai dengan maksud dan tujuan Perseroan.

2. Mewakili Perseroan untuk melakukan perbuatan hukum baik di dalam maupun di luar pengadilan sesuai dengan ketentuan Undang-Undang Perseoan Terbatas dan anggaran dasar.

Kewenangan direksi untuk mewakili Perseroan bersifat tidak terbatas dan tidak bersyarat, kecuali ditentukan lain dalam Undang-Undang Perseroan Terbatas, anggaran dasar atau keputusan Rapat Umum Pemegang Saham. Seperti diketahui bahwa kewenangan Direksi termasuk dalam kewenangan atribusi.

${ }^{16}$ Soerjono Soekanto, 1983, Faktor-faktor yang Mempengaruhi Penegakan Hukum, Raja Grafindo Persada, Jakarta, hlm. 7. 
Mengingat kewenangan yang dimiliki oleh Direksi dalam hal ini BUMD yang berbentuk Perseroan Terbatas, langsung berdasarkan ketentuan Undang-Undang Perseroan Terbatas, yang memberikan kewenangan dan tanggung jawab bagi Direksi, sebagai salah satu organ dalam perseroan yang berwenang untuk pengurusan sehari-hari Perseroan, Direksi juga berwenang mewakili Perseroan baik di dalam maupun di luar pengadilan (Pasal 98 ayat (1) UUPT). Dalam kewenangan atribusi terdapat pemberian wewenang pemerintahan oleh pembuat undang-undang kepada organ pemerintahan. Berdasarkan Undang-Undang No. 30 Tahun 2014 tentang Administrasi Pemerintahan, atribusi adalah pemberian Kewenangan kepada Badan dan/atau Pejabat Pemerintahan oleh Undang-Undang Dasar Negara Republik Indonesia Tahun 1945 atau Undang-Undang.

Adanya kewenangan yang dimiliki oleh Direksi dalam suatu Perseroan, menyebabkan Direksi sangat rentan dengan permasalahan hukum, salah satunya adalah penyalahgunaan wewenang yang kemudian dikaitkan dengan kerugian Perseroan, namun dalam praktek kerugian yang timbul tersebut langsung dikategorikan sebagai kerugian keuangan negara. Hal ini merupakan konsekuensi tentang ketidaktahuan aparat penegak hukum terhadap adanya pemisahan kekayaan dalam BUMD berbentuk Persero, sehingga tidak termasuk dalam kerugian atau piutang negara. Apabila berkaitan dengan bentuk pertanggungjawaban Direksi yang telah membuat kerugian bagi BUMD maka yang berlaku adalah ketentuan yang telah diatur dalam UUPT sebagaimana dijelaskan dalam Pasal 97 UUPT.

Pembatasan dalam hal kewenangan Direksi untuk mengelola BUMD agar tidak disangkakan dengan UU Tipikor juga dengan memperjelas definisi kerugian negara yang terdapat dalam Undang-Undang Tipikor. Selain itu, perlu ditekankan pada aparat penegak hukum supaya tidak menimbulkan ketidakpastian hukum, agar tidak menganggap kerugian BUMN/BUMD adalah kerugian negara, karena terdapat pemisahan kekayaan dalam BUMN/BUMD Persero. Dalam menentukan bentuk pertanggungjawaban Direksi BUMN/BUMD Persero aparat penegak hukum harus dapat membedakan perbuatan Direksi dalam membuat keputusan merupakan perbuatan melawan hukum atau bukan perbuatan melawan hukum, mengingat bahwa BUMN/BUMD Persero mempunyai fungsi melakukan tindakan bisnis. Dalam hal apabila Direksi melakukan kesalahan yang menimbulkan kerugian pada Perseroan, maka upaya penyelesaian yang utama harus melalui penyelesaian perdata. Kecuali perbuatan yang dilakukan Direksi memenuhi unsur-unsur Tindak Pidana, seperti tindakan penggelapan, pemalsuan data dan laporan keuangan atau menggunakan dana PSO untuk kepentingan pribadi. ${ }^{17}$ Dalam hal ini para penegak hukum khususnya, harus dapat membedakan perbuatan yang dilakukan dalam hal ini oleh Direksi, merupakan perbuatan melawan hukum atau tidak, dan termasuk dalam ranah hukum apa. Karena tidak semua perbuatan Direksi yang diduga melanggar hukum termasuk dalam perbuatan melawan hukum pidana. Begitu juga dengan dugaan terhadap Pasal 2 dan Pasal 3 UU Tipikor yang ditujukan kepada Direksi Perseroan Terbatas, dalam hal ini semua unsur harus terpenuhi terlebih dahulu, baru dapat dikatakan terbukti melakukan tindakan tersebut. Karena bisa saja perbuatan yang dilakukan tersebut tidak termasuk dalm ranah pidana, melainkan hanya bersifat keputusan bisnis, yang tentu tidak dapat digugat secara pidana. Pada tanggal 29 Desember 2016 telah dikeluarkan Peraturan Mahkamah Agung tentang Tata Cara Penanganan Tindak Pidana oleh Korporasi (Peraturan Mahkamah Agung Nomor 13 Tahun 2016 Tentang Pertanggungjawaban Pidana Bagi Korporasi). Perma tersebut disusun oleh

\footnotetext{
${ }^{17}$ Ahmad Mahyani, Jurnal Hukum Bisnis Bonum Commune Volume 2 Nomor 1, Februari 2019 Fakultas Hukum Universitas 17 Agustus 1945 Surabaya, hlm. 9.
} 
Mahkamah Agung dengan melibatkan masukan dari Komisi Pemberantasan Korupsi serta Kepolisian dan Kejaksaan. Pada pembuatannya melibatkan berbagai ahli, praktisi dan pemangku kepentingan. Perma tersebut diharapkan dapat menjadi pedoman bagi seluruh aparat penegak hukum serta menjawab berbagai persoalan yang dihadapi selama ini khususnya terkait tindak pidana korupsi dan pencucian uang. Disisi lain, diharapkan Perma ini dapat memberikan kepastian hukum kepada korporasi sehingga adanya dorongan untuk melakukan penecegahan korupsi. Perma yang ditetapkan pada tanggal 21 Desember 2009 tersebut, mengatur beberapa hal penting. Pertama, penjelasan ketentuan umum yang menjelaskan berbagai hal termasuk bentuk korporasi baik berbadan hukum maupun tidak berbadan hukum dan pengurus yang juga meliputi penerima manfaat (beneficial ownership). Kedua, Perma tersebut mengatur mengenai perbuatan dan beberapa bentuk kesalahan dari korporasi. Melalui hal tersebut maka diharapkan memberikan pedoman bagi hakim dalam menilai kesalahan oleh korporasi walaupun masih membuka peluang hakim dalam menemukan bentuk kesalahan korprorasi lainnya. Ketiga, perma tersebut mengatur mengenai tata cara penanganan perkara dengan pelaku tindak pidana korporasi, mulai dari bagaimana tata cara pemeriksaan sampai dengan penanganan korporasi induk, subsidiari dan yang berhubungan serta korporasi yang melakukan peleburan, penggabungan, pengambilalihan serta pemisahan. Keempat, Perma tersebut mengatur mengenai tata cara penanganan aset korporasi termasuk kebolehan bentuk penyimpanan berupa uang hasil penjualan aset korporasi yang disita dengan potensi nilai ekonomi yang menurun sampai adanya putusan. Kelima, Perma ini mengatur mengenai eksekusi denda, uang pengganti, restitusi serta sanksi lainnya. Untuk itu, pembentuk undang-undang (Dewan Perwakilan Rakyat) perlu mengakomodasi substansi Perma No. 13 Tahun 2016 dalam pembaruan KUHP dan KUHAP tersebut untuk dapat mengatasi kekosongan hukum dan mendorong efektivitas penanggulangan tindak pidana korporasi, serta mengetahui batasan terkait subjek tindak pidana yang dapat dijerat dengan ketentuan Pasal 2 dan 3 Undang-Undang Tipikor, serta mengetahui lebih jelas tentang tata cara penanganan kasus korupsi yang melibatkan korporasi, termasuk Direksi sebagai pengurus perseroan.

\section{KESIMPULAN}

Berdasarkan hasil penelitian dan analisis terhadap hasil penelitian diatas, maka dapat disimpulkan bahwa:

1. Pasal 2 dan Pasal 3 UU Tipikor tidak memenuhi asas dalam perumusan tindak pidana yaitu lex certa (harus jelas dan tidak multitafsir) dan lex stricta artinya rumusan tindak pidana itu harus dimaknai tegas dan ketat dan dilarang untuk menganalogikan sehingga tidak mencerminkan kepastian hukum dan bertentangan dengan Pasal 28 D ayat (1) yaitu setiap orang berhak atas pengakuan, jaminan, perlindungan, dan kepastian hukum yang adil serta perlakuan yang sama dihadapan hukum. Unsur melawan hukum "“wederrechtelijk" dalam hukum pidana sering dicampuradukan dengan pengertian pengertian melawan hukum "onrechmatigedaad" dalam hukum perdata. Tidak diaturnya kriteria dari pada unsur "memperkaya" dan atau unsur "menguntungkan" sehingga dapat berdampak multitafsir saat interpretasinya. Serta definisi dapat merugikan keuangan negara atau perekonomian negara yang tidak jelas dan tidak ada standartnya. Dari segi subjek hukum, tidak secara tegas disebutkan bahwa Direksi BUMD merupakan subjek hukum yang dimaksud Pasal 2 maupun Pasal 3 UU Tipikor. Selain itu untuk dapat dijerat dengan pasal tersebut, harus terpenuhi pula unsur merugikan keuangan negara, namun seperti diketahui bahwa keuangan BUMD Persero bukanlah keuangan negara, melainkan keuangan Perseroan Terbatas sebagai badan hukum. Terdapat perbedaan konsep keuangan negara dengan keuangan BUMD. Keuangan BUMD yang telah dikelola oleh sebuah Perseoan Terbatas sebagai badan hukum, maka keuangannya 
merupakan keuangan Perseoan Terbatas tersebut.

2. Salah satu asas yang menjadi prinsip dasar atau petunjuk sekaligus batasan bagi penegakan hukum yang memberikan ketegasan kepastian hukum dan keadilan yang terdapat dalam Undang-Undang Perseroan Terbatas yaitu asas atau prinsip Business Judgement Rule. Berdasarkan doktrin tersebut, apabila direksi pada saat mengambil keputusan, telah melakukannya dengan pertimbangan yang matang, penuh tanggung jawab, maka mengingat suasana bisnis yang penuh ketidakpastian, seandainya ternyata keputusan tersebut salah, seharusnya direksi tidak dituntut secara pribadi, karena perseroan juga harus ikut menanggung kerugian tersebut. Konsep business judgement rule telah diadopsi dalam Pasal 97 ayat (5) UUPT. Dengan demikian, tanggung jawab direksi dalam pengelolaan BUMD lebih condong kepada pertanggungjawaban perdata karena dalam hal ini termasuk bagian dari hukum privat dan bukan ranah hukum publik.

\section{REFERENSI}

\section{Buku-Buku:}

Abdulkadir Muhammad, Hukum Perusahaan Indonesia, Bandung, PT. Citra Aditya Bakti, 2010.

Darwan Prinst, 2002, Pemberantasan Tindak Pidana Korupsi, PT Citra Aditya Bakti, Bandung.

Erman Rajagukguk, 2006, Tetes Pemikiran 1971-2006, Lembaga Studi Hukum dan Ekonomi, Depok, Universitas Indonesia.

H. Abdul Latif, 2014, Hukum Administrasi Dalam Praktik Tindak Pidana Korupsi, Prenada Media Group, Jakarta.

Johnny Ibrahim, 2007, Teori \& Metodologi Penelitian Hukum Normatif, cet. III, Malang.
Mestika Zed, 2007, Metode Penelitian Kepustakaan, Yayasan Obor Indonesia, Jakarta.

Muladi \& Dwidja Priyanto, 2012, Pertanggungjawaban Pidana Korporasi, Edisi Revisi, Cetakan Ketiga, Sekolah Tinggi Hukum Bandung, Jakarta.

Nur Basuki Minarno, 2009, Penyalahgunaan Wewenang dan Tindak Pidana Korupsi dalam Pengelolaan Keuangan Daerah, Cetakan Kedua, Yogyakarta.

Romli Atmasasmita \& Kodrat Wibowo, 2016, Analisis Ekonomi Mikro tentang Hukum Pidana Indonesia, Cetakan kesatu, Prenadamedia Group, Jakarta.

Ronny Hanitijo Soemitro, 1990, Metodologi Penelitian Hukum, Ghalia Indonesia, Jakarta.

Soerjono Soekanto, 1983, Faktor-faktor yang Mempengaruhi Penegakan Hukum, Raja Grafindo Persada, Jakarta.

Sudarsono, 2007, Pengantar Ilmu Hukum, Rineka Cipta, Jakarta.

Tuti Rastuti, 2015, Seluk Beluk Perusahaan \& Hukum Perusahaan, Rafika Aditama Bandung.

\section{Jurnal :}

Ahmad Mahyani, Jurnal Hukum Bisnis Bonum Commune Volume 2 Nomor 1, Februari 2019 Fakultas Hukum Universitas 17 Agustus 1945 Surabaya.

\section{Website:}

https://mediaindonesia.com/read/detail/189924business-judgment-rule-versustindak-pidana-korupsi, diakses pada 1 April 2019.

Heyder Affan, Dahlan Iskan Dan Tiga Kasus Dugaan Korupsi Yang Menjerat Dirinya, dalam 
http://www.bbc.com/indonesia/indo nesia38851898, diunduh pada 3 Januari 2019.

Dian Kurniawan, Alasan Dahlan Iskan Jual Aset Panca Wira, dalam http://regional.liputan6.com/read/29 10595/alasan-dahlan-iskan-jualaset-pancawira, diunduh pada 3 Januari 2019.

\section{Peraturan Perundang-Undangan:}

Undang-Undang Dasar Negara Republik Indonesia Tahun 1945.

Undang-Undang Nomor 31 Tahun 1999 tentang Pemberantasan Tindak Pidan Korupsi.

Undang-Undang Nomor 40 Tahun 2007 tentang Perseroan Terbatas. 
